\title{
Short communication: Relationship between body condition score and plasma adipokines in early-lactating Holstein dairy cows
}

\author{
M. Mansouryar, ${ }^{* 1}$ H. Mirzaei-Alamouti, ${ }^{*}$ M. Dehghan Banadaky, † H. Sauerwein, $\ddagger$ M. Mielenz,§ \\ and M. O. Nielsen\# \\ *Department of Animal Science, University of Zanjan, Zanjan 45371-38791, Iran \\ †Department of Animal Science, University of Tehran, Karak 31587-77871, Iran \\ łInstitute of Animal Science, Physiology and Hygiene Unit, University of Bonn, 53115 Bonn, Germany \\ §Institute of Nutritional Physiology "Oskar Kellner," Leibniz Institute for Farm Animal Biology (FBN), 18196 Dummerstorf, Germany \\ \#Department of Veterinary and Animal Sciences, University of Copenhagen, Frederiksberg C 1870, Denmark
}

\section{ABSTRACT}

We hypothesized that plasma adipokine concentrations of early-lactation dairy cows are related to body condition score (BCS) at calving and to markers of metabolic status of the cow. As part of a larger study with 117 multiparous Holstein dairy cows, which had high BCS (BCS >4.0) or normal BCS (3.25-3.5) at calving, 22 cows were randomly selected ( $\mathrm{n}=11$ per group) to be enrolled in this study. Cows were divided into 2 groups based on their BCS at calving: (1) normal BCS with BCS of $3.35 \pm 0.13$ (mean \pm SD) and (2) high BCS cows with BCS of $4.14 \pm 0.17$. The 22 selected animals did not have a clinically diagnosed health problem after calving. Blood samples were taken right after calving (d 1) and before morning feeding on d 8,15 , and 21 postpartum concurrently with body condition scoring for all cows. Blood samples were analyzed for plasma adiponectin, leptin, tumor necrosis factor- $\alpha$, and IL-6. The mean BCS remained highest in high-BCS cows during the first $21 \mathrm{~d}$ in milk. Leptin concentrations decreased progressively for all cows after calving. However, differences in BCS at calving were not related to leptin concentrations. Adiponectin, IL-6, and tumor necrosis factor- $\alpha$ concentrations were neither influenced by days in milk nor BCS after calving. Leptin and the leptin-to-adiponectin ratio did not show any correlation at any time point during the first 21 $\mathrm{d}$ in milk with plasma concentrations of nonesterified fatty acids or $\beta$-hydroxybutyrate, which are considered as markers of metabolic status. Only for IL- 6 at $d 8$ did we find a strong correlation with metabolic status indicators. In conclusion, plasma adipokine concentra-

Received November 10, 2017.

Accepted April 7, 2018.

${ }^{1}$ Corresponding author: mansooryar@znu.ac.ir tions during the first 3 wk postpartum were not related to BCS in lactating Holstein cows that were clinically healthy at calving.

Key words: dairy cow, leptin, adiponectin, tumor necrosis factor- $\alpha$, interleukin- 6

\section{Short Communication}

Adipose tissue is an important endocrine organ that secretes several bioactive molecules termed adipokines, which are involved in the regulation of whole body metabolism and immune responses (Fantuzzi, 2005; Trayhurn et al., 2006). Adiponectin and leptin are among the most important adipokines in the control of energy homeostasis (Havel, 2002). In humans, plasma leptin concentrations are positively correlated with degree of adiposity (Considine et al., 1996) and insulin resistance (Matsubara et al., 2000). In general, low concentrations of adiponectin are associated with an obese phenotype and with the release of inflammatory proteins (Weyer et al., 2001; Yang et al., 2001). Concentrations of these 2 adipokines in plasma have been associated with the occurrence of certain metabolic diseases, and it has been proposed that they can be used as chemical markers for diagnosis of obesity and obesity-related disorders in humans (Considine et al., 1996; Shimomura et al., 1999). Moreover, the ratio of leptin to adiponectin has been suggested as a potential index for obesity in some mammalian species, such as cynomolgus monkeys (Chen et al., 2003), and as a potential index for coexistence of obesity and type 2 diabetes mellitus in human patients (Satoh et al., 2004). Concentrations of other adipokines in plasma are also increased in the obese state. Tumor necrosis factor- $\alpha$ (TNF- $\alpha)$ and IL-6 are 2 important proinflammatory adipokines that promote insulin resistance, and they have been linked with obesity-related diseases such as diabetes type 2 (Goyal et al., 2012). In addition, it is known that adiponectin is correlated negatively with TNF- $\alpha$ and IL-6 (Lira et al., 
2011). Concentrations of IL-6 in plasma are positively associated with the severity of inflammatory response in early-lactating dairy cows (Trevisi et al., 2012), and IL-6 has been suggested as a predictive marker for diagnosis of animals that may fail to have a successful transition period (Trevisi et al., 2015).

It has been documented that cows with a high BCS at calving have lowered postpartal daily DMI and experience a more severe negative energy balance (NEB) with more extensive mobilization of body fat postpartum (Roche et al., 2009). Most studies claim that NEB is the most influential factor in predisposing overconditioned cows to different postpartal metabolic diseases (Hayirli et al., 2002; Roche et al., 2009). However, knowledge is lacking regarding the role played by the adipose-derived adipokines in regulation of metabolic status and inflammation and in the development of transition disorders in early-lactating dairy cows. We hypothesized that concentrations of important adiposederived adipokines in plasma in early-lactating dairy cows are related to BCS of the cow at calving and that concentrations of these adipokines can be used as markers for metabolic status of the early-lactating dairy cow. The objectives of this study were to determine (1) whether BCS and BCS changes across the postpartal period are related to concentrations of adipose-derived adipokines in plasma in early lactation and (2) whether changes in concentrations of adipokines in plasma in early lactation are related to changes in commonly used metabolic markers.

The Committee for Animal Care and Use, University of Zanjan, Iran, approved the experimental and management protocols of this study. Body condition score was scored immediately after parturition (1 DIM) based on the 1 to 5 scale described by Ferguson et al. (1994). Among a larger group of 117 cows, 11 clinically healthy cows with a BCS between 3.25 and 3.5 at calving were assigned to a normal-BCS (NBCS) group, and 11 clinically healthy cows with a BCS $\geq 4$ were assigned to a high-BCS (HBCS) group. Before parturition, all cows had been fed the same diet, which was formulated to meet energy and nutritional requirements according to the NRC (2001). All animals were fed the same diet postpartum, which was formulated to meet requirements for lactating dairy cows according to the NRC (2001).

Throughout the experimental period, the cows were housed in open barns with straw bedding. Both preand postpartum diets were offered ad libitum as a TMR twice daily (at 0600 and $1430 \mathrm{~h}$ ). Fresh water was available at all times for all animals. Early-lactating cows were milked 3 times daily at 0500,1230 , and $2000 \mathrm{~h}$. Milk yield was recorded once weekly at d 8, 15, and 21 postpartum. Concurrently, milk samples from each of the 3 daily milkings were taken, pooled, and stored at $-21^{\circ} \mathrm{C}$ until analysis for fat and protein concentrations by using a Milko-Scan 33 (Foss Electric, Hillerød, Denmark). Energy-corrected milk (4\% fat, $3.3 \%$ protein) was calculated using the following equation: $\mathrm{ECM}=$ (milk production $\times 0.383 \times$ fat $\%+$ milk production $\times$ $0.242 \times$ protein $\%+0.7832 \times$ milk production) $/ 3.1138$. Blood samples were collected by venipuncture from the coccygeal vein right after birth (d 1) and on d 8, 15, and 21 postpartum before the morning feeding. Blood was collected into heparinized vacutainer tubes, and plasma was separated immediately after by centrifugation at $1,300 \times g$ for $15 \mathrm{~min}$ at $4^{\circ} \mathrm{C}$. Aliquots of plasma were stored at $-80^{\circ} \mathrm{C}$ for later analyses. Plasma leptin was analyzed with an enzyme immunoassay that has been validated for use in several species, including bovine (Sauerwein et al., 2004). The mean intra-assay coefficient of variation was $3 \%$, and the inter-assay coefficient of variation was $3.4 \%$. Plasma adiponectin was analyzed by a competitive ELISA, as described by Mielenz et al. (2013). The intra- and inter-assay coefficients of variation were 5.6 and $8.2 \%$, respectively. Concentrations of IL- 6 and TNF- $\alpha$ in plasma were determined by commercial high sensitive ELISA kits for bovine IL-6 (kit SEA079Bo; USCN Life Science, Wuhan, China) and bovine TNF- $\alpha$ (kit Q06599; Thermo Fisher Scientific Inc., Waltham, MA), respectively. Nonesterified fatty acid (NEFA; Wako Chemicals, Neuss, Germany; kit 436-91995) and BHB (kit RB 1008; Labor und Technik, Berlin, Germany) concentrations were measured in plasma by using an ABX Pentra 400 instrument (Horiba Medical, Kyoto, Japan).

All data were analyzed by using SPSS 21.0 (SPSS Inc., Chicago, IL). Analysis of variance for repeated measures was used to test the effect of BCS through time for all blood parameters. In this analysis, time was considered repeated with 4 levels [1 (day of calving), 8 , 15 , and 21 DIM]. In the analyses of blood parameters, within-animal factors and group as the between-animal factor were included in the models to test for differences between the 2 groups of animals with respect to changes of parameters over the first $21 \mathrm{~d}$ postpartum. Tukey test was used for the determination of differences between BCS groups. Sphericity was checked for violation with Greenhouse-Geisser corrected degrees of freedom, if this was needed (Huck, 2000). For all analyses, homogeneity of variances was tested using the Levene's test. Differences at each time point between HBCS and NBCS groups were compared by Student's $t$-test. Pearson correlation coefficients were calculated to describe relationships between the monitored variables. Moreover, simple linear regression analyses were performed 
to test the independent relations between variables that were found to be significantly correlated. Confidence interval was set at $95 \%$. Significance and tendency differences between treatments were determined at the $P$ $\leq 0.05$ and $0.05<P \leq 0.10$ levels, respectively.

The forage-to-concentrate ratio of the lactation diet was 41:59 and provided 6.86 MJ of $\mathrm{NE}_{\mathrm{L}}$ per kilogram of DM and 16.7\% CP. As shown in Table 1, milk yield, ECM, and milk fat or protein concentrations did not differ between HBCS and NBCS cows over the first 21 $\mathrm{d}$ of lactation. Milk fat and protein yields at 8, 15, and 21 DIM for NBCS and HBCS cows are shown in Supplemental Table S1 (https://doi.org/10.3168/jds.2017 -14122). The average calving BCS for HBCS and NBCS groups were $4.14 \pm 0.06$ and $3.35 \pm 0.08$, respectively (mean $\pm \mathrm{SD} ; P=0.0001$ ). Because of the higher BCS levels at calving, the HBCS cows continued to have higher BCS than the NBCS cows even at d 21 postpartum $(P<0.05)$. Concentrations of different variables in plasma at different time points during the first $21 \mathrm{~d}$ after parturition are presented in Figure 1. Despite the differences in BCS at calving and the different patterns of change in BCS after calving, concentrations of leptin in plasma were at the same level in the 2 groups of cows at calving, and leptin concentrations also decreased in the same fashion in the 2 groups of cows in early lactation (Figure 1b). No differences could be established in the pattern of changes in concentrations of TNF- $\alpha$ (slight decrease, Figure 1e) or IL-6 (slight increase, Figure 1f) in early lactation between the 2 groups of cows.

Concentrations of BHB in plasma increased markedly over the first $21 \mathrm{~d}$ of lactation, when milk production also increased $(P=0.031$; Figure $1 \mathrm{~h})$. Nonesterified fatty acids and $\mathrm{BHB}$ concentrations were not related to differences in BCS at calving, but a positive correlation was established between IL-6 at d 8 postpartum and BHB concentrations at d 8 to 15 postpartum $(P<0.01$; $\left.\mathrm{R}^{2}=0.38-0.54\right)$. Some correlations were also found for adiponectin and TNF- $\alpha$ with NEFA and for adiponectin and IL-6 with milk yield and BCS at selected time points, but these correlations were weak in all cases $(P$ $\left.<0.05 ; \mathrm{R}^{2}<0.33\right)$.

Leptin is an adipose-derived hormone, which is normally believed to be downregulated in early lactation, when net energy balance becomes negative and body fat is mobilized (Block et al., 2001). It was therefore surprising that the concentrations of leptin and adiponectin in plasma did not differ between the HBCS and NBCS cows at calving and that the changes in leptin concentrations in the HBCS cows in early lactation were not more pronounced compared with the NBCS cows. Unexpectedly, the greater rate of postpartum mobilization in the HBCS cows was not reflected in differences in concentrations of the metabolic markers NEFA and BHB in plasma, and no significant difference existed in the way concentrations of the 2 markers in plasma changed in early lactation. Other studies have established positive correlations between leptin and BCS in lactating (Chilliard et al., 2005) and nonlactating, nonpregnant cows (Locher et al., 2015), and a correlation to NEB in lactating cows depending on the stage of lactation (Chilliard et al., 2005). However, Holtenius et al. (2003) found that, similar to us, leptin concentrations were unrelated to BCS after calving in lactating, nonpregnant dairy cows.

Some studies have indicated that BCS in dairy cows during the dry period may be more closely associated with adiponectin than with leptin (Locher et al., 2015), but this negative correlation may disappear as parturition approaches, because adiponectin concentra-

Table 1. Effects of BCS at calving (NBCS and HBCS) ${ }^{1}$ on milk yield, milk composition, and ECM at 8, 15, and 21 DIM

\begin{tabular}{|c|c|c|c|c|c|c|c|}
\hline \multirow[b]{2}{*}{ Item } & \multirow[b]{2}{*}{ DIM } & \multirow[b]{2}{*}{ NBCS } & \multirow[b]{2}{*}{ HBCS } & \multirow[b]{2}{*}{$\mathrm{SE}$} & \multicolumn{3}{|c|}{$P$-value } \\
\hline & & & & & Group & Time & Group $\times$ time \\
\hline \multirow[t]{3}{*}{ Milk yield $(\mathrm{kg} / \mathrm{d})$} & 8 & 31.6 & 28.8 & 1.2 & 0.11 & $<0.01$ & 0.55 \\
\hline & 15 & 38.6 & 34.9 & 1.6 & & & \\
\hline & 21 & 42.1 & 37.7 & 1.2 & & & \\
\hline \multicolumn{8}{|c|}{ Milk composition (\%) } \\
\hline \multirow[t]{3}{*}{ Fat } & 8 & 4.4 & 4.9 & 0.5 & 0.35 & $<0.01$ & 0.92 \\
\hline & 15 & 4.4 & 4.4 & 0.2 & & & \\
\hline & 21 & 3.4 & 4.0 & 0.2 & & & \\
\hline \multirow{3}{*}{ Protein } & 8 & 3.7 & 3.5 & 0.1 & 0.80 & $<0.01$ & 0.40 \\
\hline & 15 & 3.1 & 3.3 & 0.1 & & & \\
\hline & 21 & 2.9 & 2.9 & 0.4 & & & \\
\hline \multirow[t]{3}{*}{$\operatorname{ECM}(\mathrm{kg} / \mathrm{d})$} & 8 & 34.2 & 32.9 & 2.0 & 0.52 & 0.15 & 0.95 \\
\hline & 15 & 39.6 & 36.9 & 2.2 & & & \\
\hline & 21 & 37.8 & 36.2 & 1.3 & & & \\
\hline
\end{tabular}

${ }^{1} \mathrm{NBCS}=$ normal BCS $(3.25-3.50), \mathrm{n}=11 ; \mathrm{HBCS}=$ high BCS $(\geq 4.0), \mathrm{n}=11$. 

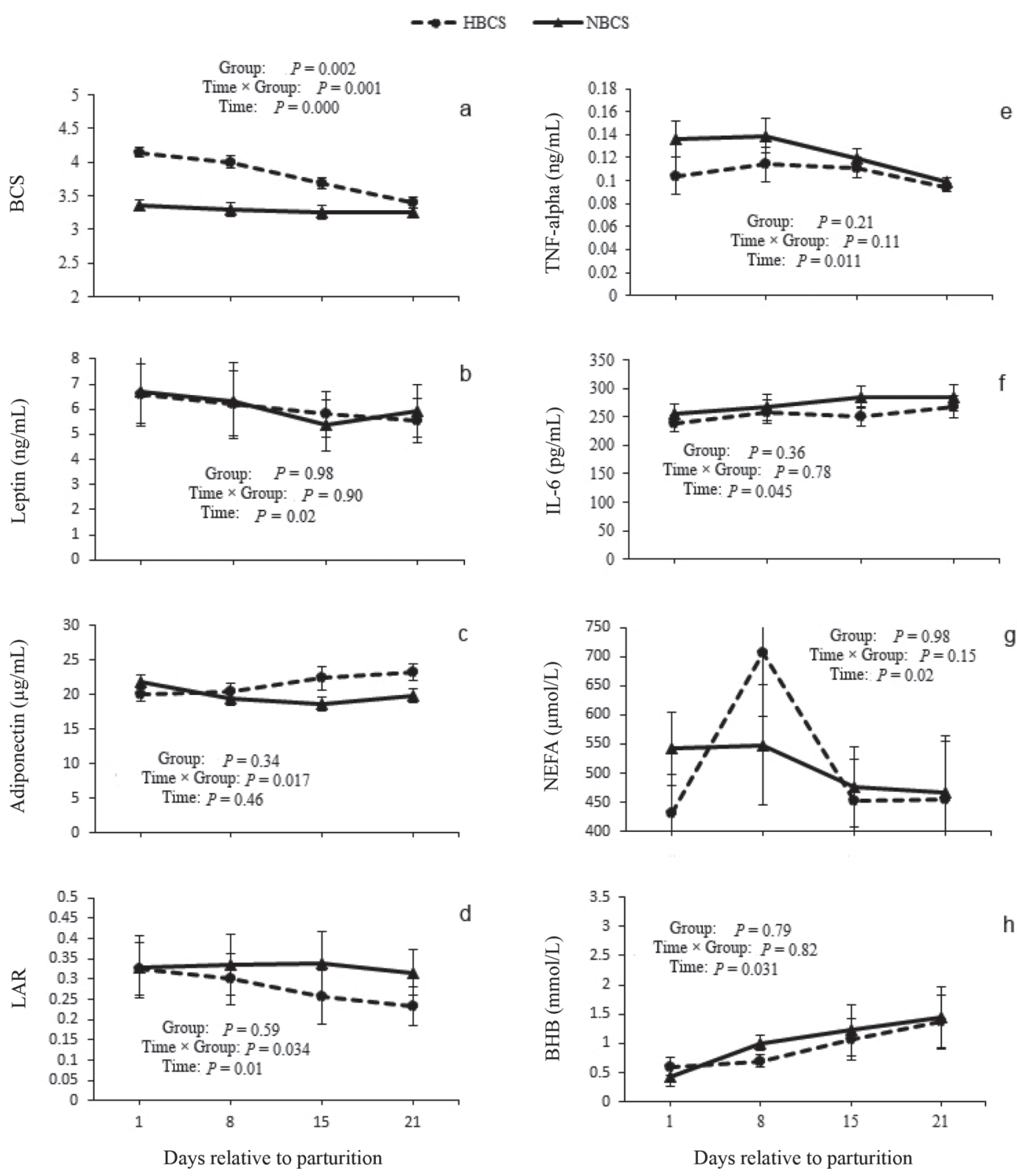

Figure 1. Body condition score changes; plasma concentrations of leptin and adiponectin; the ratio of leptin to adiponectin concentrations (LAR); and plasma concentrations of tumor necrosis factor- $\alpha$ (TNF- $\alpha$ ), IL-6, nonesterified fatty acids (NEFA), and BHB (LSM \pm SEM) in early lactation in cows with high BCS (HBCS; $\mathrm{n}=11$; BCS $>4.0 ; \bullet$ ) versus normal BCS (NBCS; $\mathrm{n}=11$; $\mathrm{BCS}=3.25-3.5$; $\mathbf{\Delta}$ ) at calving.

tions gradually approach a nadir at this time point (De Koster et al., 2017). During early lactation, loss of adiposity associated with NEB may thus become more important in determining adiponectin concentrations, rather than the degree of body fatness per se (Giesy et al., 2012; Singh et al., 2014; De Koster et al., 2017). It may explain why the extent of body fatness in our experiment was not associated with either leptin concentration or leptin-to-adiponectin ratio at calving, and the correlations found between adiponectin and BCS were weak. Thus, in contrast to results of human studies (Oda et al., 2008), we and others (Singh et al., 2014) have been unable to find any evidence to suggest that leptin and leptin-to-adiponectin ratio could be useful markers for metabolic disorders in the bovine animal.

Tumor necrosis factor- $\alpha$ was the first adipokine for which it was shown that its concentrations in blood increase in obese humans, and concentrations decrease 
after weight loss (Dandona et al., 1998). Tumor necrosis factor- $\alpha$ has a stimulatory effect on leptin formation (Zumbach et al., 1997) and inhibits adiponectin secretion in rodents (Ruan et al., 2002). However, in our study, because of the different patterns of changes of these hormones in the early postpartum period, no such correlations could obviously be established. Observations regarding the association between BCS and concentrations of TNF- $\alpha$ in plasma of dairy cows are conflicting. In a study by O'Boyle et al. (2006), highBCS, mid-lactating dairy cows $(>3.5)$ were found to have higher TNF- $\alpha$ concentrations compared with their normal counterparts (BCS 2.5-2.7), as in the human study (Dandona et al., 1998). However, Ohtsuka et al. (2001) failed to establish any relation between BCS and TNF- $\alpha$ concentrations in plasma of dairy cows suffering from fatty liver, and in a study by Røntved et al. (2005), TNF- $\alpha$ concentrations in plasma were unaffected by changes in energy status of dairy cows in early lactation. These latter observations are in line with our study, where we were unable to demonstrate any significant differences in TNF- $\alpha$ concentrations in plasma between HBCS and NBCS cows at any time point during early lactation. If anything, HBCS cows had the numerically lowest concentrations, particularly at calving, compared with the NBCS cows (Figure 1e), opposite of what was observed in humans (Dandona et al., 1998). Unlike adiponectin and leptin, which are secreted almost exclusively by adipocytes, TNF- $\alpha$ is secreted mainly from macrophages and less from adipocytes (Maury et al., 2009). Thus, it is reasonable to assume that the inflammatory state of the cow has a much more dominant role in determining concentrations of TNF- $\alpha$ in plasma compared with NEB. Nonesterified fatty acids and BHB concentrations in plasma in this study never reached levels that indicate a degree of ketonemia, which would have been expected to elicit a response in this inflammatory marker (Abuajamieh et al., 2016), and changes in concentrations of NEFA and BHB were not related to those of TNF- $\alpha$. We speculate that physiological factors, such as the time interval to parturition, may have a greater influence on TNF- $\alpha$ concentrations in plasma than adiposity per se in the apparently healthy periparturient dairy cow, and this assumption is supported by observations that plasma TNF- $\alpha$ increases as parturition approaches and decreases thereafter (Ametaj et al., 2005), as we also observed.

Our results showed that the only adipokine related to the 2 metabolic markers NEFA and BHB in clinically healthy cows was IL-6. Plasma IL-6 at d 8 postpartum was positively correlated with NEFA at d $21(\mathrm{r}=0.54$, $P=0.025)$ and with BHB at $\mathrm{d} 8,15$, and $21(\mathrm{r}=0.67$, $\mathrm{r}=0.62$, and $\mathrm{r}=0.72$, respectively; $P<0.01$ ). These results are in agreement with other studies, where IL-6 concentration has been linked to metabolic changes observed in ketotic cows (Loor et al., 2007; Zhang et al., 2016) and to the severity of inflammatory responses in early-lactating dairy cows (Trevisi et al., 2012). Dairy cows in this study were under a high management level, and the periparturient diets contained propylene glycol, a gluconeogenic substrate that is given to promote glucose supply for milk synthesis and to prevent excessive fat mobilization and ketosis (Christensen et al., 1997). Therefore, this may explain, in part, why the postpartum increases in NEFA level in HBCS were relatively modest to low in most of the time points in early lactation $(<550 \mu \mathrm{mol} / \mathrm{L})$. The picture could be different in cows with more extensive fat mobilization, resulting in higher NEFA concentrations. Thus, our study suggests that BCS is not a major determining factor of adipokine levels after calving; rather, such changes may be related to an adipose-tissue dysfunction following extensive fat mobilization.

Finally, the anatomical location of body fat mobilization may affect the concentrations of adipokines in plasma, and the limitations of the BCS method used in this study obviously relate to the fact that it primarily reflects changes in fat mass of subcutaneous and peripheral adipose tissues. It has been shown in humans that plasma adiponectin, IL-6, and TNF- $\alpha$ are more strongly influenced by the amount of visceral fat (Park et al., 2005; Fontana et al., 2007) than by subcutaneous fat, and other factors influenced by NEB could potentially influence the set point for their release from adipose tissues (Chilliard et al., 2005; De Koster et al., 2017).

In conclusion, body condition at calving did not have any major effect on concentrations of leptin, adiponectin, IL-6, or TNF- $\alpha$ in plasma of clinically healthy early-lactating dairy cows. Interleukin-6 was the only adipokine for which we could find indications of an upregulation when concentrations of the metabolic markers NEFA and BHB in plasma for NEB were increased, but the association between changes in IL- 6 and degree of fatness of the cow was not significant. Further studies are needed to resolve the underlying reasons for, and implications of, the association of IL-6 with metabolic status in early-lactating dairy cows.

\section{ACKNOWLEDGMENTS}

This research project was funded by University of Zanjan. The staff at Behroozi Farm Co. are also acknowledged for their support and consideration. 


\section{REFERENCES}

Abuajamieh, M., S. K. Kvidera, M. V. Sanz Fernandez, A. Nayeri, N. C. Upah, E. A. Nolan, S. M. Lei, J. M. DeFrain, H. B. Green, K. M. Schoenberg, W. E. Trout, and L. H. Baumgard. 2016. Inflammatory biomarkers are associated with ketosis in periparturient Holstein cows. Res. Vet. Sci. 109:81-85.

Ametaj, B. N., B. J. Bradford, G. Bobe, R. A. Nafikov, Y. Lu, J. W. Young, and D. C. Beitz. 2005. Strong relationships between mediators of the acute phase response and fatty liver in dairy cows. Can. J. Anim. Sci. 85:165-175.

Block, S. S., W. Butler, R. Ehrhardt, A. Bell, M. Amburgh, and Y. Boisclair. 2001. Decreased concentration of plasma leptin in periparturient dairy cows is caused by negative energy balance. J. Endocrinol. 171:339-348.

Chen, Y., H. Ogawa, H. Narita, K. Ohtoh, T. Yoshida, and Y. Yoshikawa. 2003. Ratio of leptin to adiponectin as an obesity index of cynomolgus monkeys (Macaca fascicularis). Exp. Anim. 52:137-143.

Chilliard, Y., C. Delavaud, and M. Bonnet. 2005. Leptin expression in ruminants: Nutritional and physiological regulations in relation with energy metabolism. Domest. Anim. Endocrinol. 29:3-22.

Christensen, J. O., R. R. Grummer, F. E. Rasmussen, and S. J. Bertics. 1997. Effect of method of delivery of propylene glycol on plasma metabolites of feed-restricted cattle. J. Dairy Sci. 80:563-568.

Considine, R. V., M. K. Sinha, M. L. Heiman, A. Kriauciunas, T. W. Stephens, M. R. Nyce, J. P. Ohannesian, C. C. Marco, L. J. McKee, T. L. Bauer, and J. F. Caro. 1996. Serum immunoreactive-leptin concentrations in normal weight and obese humans. N. Engl. J. Med. 334:292-295.

Dandona, P., R. Weinstock, K. Thusu, E. Abdel-Rahman, A. Aljada, and T. Wadden. 1998. Tumor necrosis factor-alpha in sera of obese patients: Fall with weight loss. J. Clin. Endocrinol. Metab. 83:2907-2910.

De Koster, J., C. Urh, M. Hostens, W. Van Den Broeck, H. Sauerwein, and G. Opsomer. 2017. Short Communication: Relationship between serum adiponectin concentration, body condition score and peripheral tissue insulin response of dairy cows during the dry period. Domest. Anim. Endocrinol. 59:100-104.

Fantuzzi, G. 2005. Adipose tissue, adipokines, and inflammation. J. Allergy Clin. Immunol. 115:911-919.

Ferguson, J. D., D. T. Galligan, and N. Thomsen. 1994. Principal descriptors of body condition score in Holstein cows. J. Dairy Sci. 77:2695-2703.

Fontana, L., J. C. Eagon, M. E. Trujillo, P. E. Scherer, and S. Klein. 2007. Visceral fat adipokine secretion is associated with systemic inflammation in obese humans. Diabetes 56:1010-1013.

Giesy, S. L., B. Yoon, W. B. Currie, J. W. Kim, and Y. R. Boisclair. 2012. Adiponectin deficit during the precarious glucose economy of early lactation in dairy cows. Endocrinology 153:5834-5844.

Goyal, R., A. F. Faizy, S. S. Siddiqui, and M. Singhai. 2012. Evaluation of TNF- $\alpha$ and IL-6 levels in obese and non-obese diabetics: Pre- and postinsulin effects. N. Am. J. Med. Sci. 4:180-184.

Havel, P. J. 2002. Control of energy homeostasis and insulin action by adipocyte hormones: Leptin, acylation stimulating protein, and adiponectin. Curr. Opin. Lipidol. 13:51-59.

Hayirli, A., R. R. Grummer, E. V. Nordheim, and P. M. Crump. 2002. Animal and dietary factors affecting feed intake during the prefresh transition period in Holsteins. J. Dairy Sci. 85:3430-3443.

Holtenius, K., S. Agenäs, C. Delavaud, and Y. Chilliard. 2003. Effects of feeding intensity during the dry period. Part 2. Metabolic and hormonal responses. J. Dairy Sci. 86:883-891.

Huck, S. W. 2000. Reading Statistics and Research. 3rd ed. Longman, New York, NY.

Lira, F. S., J. C. Rosa, R. V. dos Santos, D. P. Venancio, J. Carnier, P. de Lima Sanches, C. M. O. do Nascimento, A. de Piano, L. Tock, S. Tufik, and M. T. de Mello. 2011. Visceral fat decreased by long-term interdisciplinary lifestyle therapy correlated positively with interleukin- 6 and tumor necrosis factor- $\alpha$ and negatively with adiponectin levels in obese adolescents. Metabolism 60:359-365.
Locher, L., S. Häussler, L. Laubenthal, S. P. Singh, J. Winkler, A. Kinoshita, Á. Kenéz, J. Rehage, K. Huber, H. Sauerwein, and S. Dänicke. 2015. Effect of increasing body condition on key regulators of fat metabolism in subcutaneous adipose tissue depot and circulation of nonlactating dairy cows. J. Dairy Sci. 98:1057-1068.

Loor, J. J., R. E. Everts, M. Bionaz, H. M. Dann, D. E. Morin, R. Oliveira, S. L. Rodriguez-Zas, J. K. Drackley, and H. A. Lewin. 2007. Nutrition-induced ketosis alters metabolic and signaling gene networks in liver of periparturient dairy cows. Physiol. Genomics 32:105-116.

Matsubara, M., H. Chiba, S. Maruoka, and S. Katayose. 2000. Elevated serum leptin concentrations in women with components of multiple risk factors clustering syndrome. J. Atheroscler. Thromb. 7:231-237.

Maury, E., L. Noël, R. Detry, and S. M. Brichard. 2009. In vitro hyperresponsiveness to tumor necrosis factor- $\alpha$ contributes to adipokine dysregulation in omental adipocytes of obese subjects. J. Clin. Endocrinol. Metab. 94:1393-1400.

Mielenz, M., B. Mielenz, S. P. Singh, C. Kopp, J. Heinz, S. Häussler, and H. Sauerwein. 2013. Development, validation and pilot application of a semi-quantitative Western blot and a sandwich ELISA for bovine adiponectin. Domest. Anim. Endocrinol. 44:121-130.

NRC. 2001. Nutrient Requirements of Dairy Cattle. 7th rev. ed. Natl. Acad. Sci., Washington, DC.

O'Boyle, N., C. M. Corl, J. C. Gandy, and L. M. Sordillo. 2006. Relationship of body condition score and oxidant stress to tumor necrosis factor expression in dairy cattle. Vet. Immunol. Immunopathol. 113:297-304

Oda, N., S. Imamura, T. Fujita, Y. Uchida, K. Inagaki, H. Kakizawa, N. Hayakawa, A. Suzuki, J. Takeda, Y. Horikawa, and M. Itoh. 2008. The ratio of leptin to adiponectin can be used as an index of insulin resistance. Metabolism 57:268-273.

Ohtsuka, H., M. Koiwa, A. Hatsugaya, K. Kudo, F. Hoshi, N. Itoh, H. Yokota, H. Okada, and S. Kawamura. 2001. Relationship between serum TNF activity and insulin resistance in dairy cows affected with naturally occurring fatty liver. J. Vet. Med. Sci. 63:1021-1025.

Park, H. S., J. Y. Park, and R. Yu. 2005. Relationship of obesity and visceral adiposity with serum concentrations of CRP, TNF-alpha and IL-6. Diabetes Res. Clin. Pract. 69:29-35.

Roche, J. R., N. C. Friggens, J. K. Kay, M. W. Fisher, K. J. Stafford, and D. P. Berry. 2009. Invited review: Body condition score and its association with dairy cow productivity, health, and welfare. J. Dairy Sci. 92:5769-5801.

Røntved, C. M., J. B. Andersen, J. Dernfalk, and K. L. Ingvartsen. 2005. Effects of diet energy density and milking frequency in early lactation on tumor necrosis factor-alpha responsiveness in dairy cows. Vet. Immunol. Immunopathol. 104:171-181.

Ruan, H., P. D. Miles, C. M. Ladd, K. Ross, T. R. Golub, J. M. Olefsky, and H. F. Lodish. 2002. Profiling gene transcription in vivo reveals adipose tissue as an immediate target of tumor necrosis factor-alpha: Implications for insulin resistance. Diabetes $51: 3176-3188$.

Satoh, N., M. Naruse, T. Usui, T. Tagami, T. Suganami, K. Yamada, H. Kuzuya, A. Shimatsu, and Y. Ogawa. 2004. Leptin-to-adiponectin ratio as a potential atherogenic index in obese type 2 diabetic patients. Diabetes Care 27:2488-2490.

Sauerwein, H., U. Heintges, M. Hennies, T. Selhorst, and A. Daxenberger. 2004. Growth hormone induced alterations of leptin serum concentrations in dairy cows as measured by a novel enzyme immunoassay. Livest. Prod. Sci. 87:189-195.

Shimomura, I., R. E. Hammer, S. Ikemoto, M. S. Brown, and J. L. Goldstein. 1999. Leptin reverses insulin resistance and diabetes mellitus in mice with congenital lipodystrophy. Nature 401:73-76.

Singh, S. P., S. Häussler, J. F. L. Heinz, B. Saremi, B. Mielenz, J. Rehage, S. Dänicke, M. Mielenz, and H. Sauerwein. 2014. Supplementation with conjugated linoleic acids extends the adiponectin deficit during early lactation in dairy cows. Gen. Comp. Endocrinol. 198:13-21. 
Trayhurn, P., C. Bing, and I. S. Wood. 2006. Adipose tissue and adipokines-Energy regulation from the human perspective. J. Nutr. 136(7 Suppl.):1935S-1939S.

Trevisi, E., M. Amadori, S. Cogrossi, E. Razzuoli, and G. Bertoni. 2012. Metabolic stress and inflammatory response in high-yielding, periparturient dairy cows. Res. Vet. Sci. 93:695-704.

Trevisi, E., N. Jahan, G. Bertoni, A. Ferrari, and A. Minuti. 2015 Pro-inflammatory cytokine profile in dairy cows: Consequences for new lactation. Ital. J. Anim. Sci. 14:3862.

Weyer, C., T. Funahashi, S. Tanaka, K. Hotta, Y. Matsuzawa, R. E. Pratley, and P. A. Tataranni. 2001. Hypoadiponectinemia in obesity and type 2 diabetes: Close association with insulin resistance and hyperinsulinemia. J. Clin. Endocrinol. Metab. 86:1930-1935.
Yang, W. S., W. J. Lee, T. Funahashi, S. Tanaka, Y. Matsuzawa, C. L. Chao, C. L. Chen, T. Y. Tai, and L. M. Chuang. 2001. Weight reduction increases plasma levels of an adipose-derived anti-inflammatory protein, adiponectin. J. Clin. Endocrinol. Metab. $86: 3815-3819$

Zhang, G., D. Hailemariam, E. Dervishi, S. A. Goldansazm, Q. Deng, S. M. Dunn, and B. N. Ametaj. 2016. Dairy cows affected by ketosis show alterations in innate immunity and lipid and carbohydrate metabolism during the dry off period and postpartum. Res. Vet. Sci. 107:246-256.

Zumbach, M. S., M. W. J. Boehme, P. Wahl, W. Stremmel, R. Ziegler, and P. P. Nawroth. 1997. Tumor necrosis factor increases serum leptin levels in humans. J. Clin. Endocrinol. Metab. 82:4080-4082. 